\title{
MOST VULNERABLE CHILDREN: A CASE STUDY OF THE GOVERNMENT SCHOOLS IN MADHYA PRADESH AND CHHATTISGARH \\ Dr. Pankaj Das
}

\begin{abstract}
It still found that dropping out is a serious problem in the government schools of poor states in India. The causes may be categorized into two broad categories individual level and institutional level. Along with a host of causative factors of dropping out from the school, there are a passive segment of children who suffers a lot both emotionally and cognitively in compare to other risk children owes to their inappropriate schooling behaviour. Such types of children were found to a great extent in the government schools of Madhya Pradesh and Chhattisgarh States of India. These children were categorised as 'most vulnerable children' who are although exist in our education system but they were omitted silently without much attention to address their problem. In such context, this paper aims to explore the nature and extent of conditions of most vulnerable children in elementary education in Indian education system.
\end{abstract}

Keywords: Dropout, Most Vulnerable Children, Elementary Education, Schooling Behaviour

\section{Introduction:}

The previous research literature has given an in-depth understanding about the magnitude of vulnerability of 'risk children' in different country studies across the globe (Das, 2013; Hunt, 2008). Based on the nature of vulnerability along with other risk factors, the individual and school related risk factors (Ramachandran, V. et. al., 2003; Boyle, S. et.al. 2002; PROBE, 1999; Rumberger, R. W et.al., 1990) are important aspects of describing the acute vulnerable conditions of children who are 'at risk' of permanent exclusion of schooling.

Based on collected data on repetition, absenteeism and responses of teachers regarding performance of students, the study has discussed about the children who are at the risk of dropping out 
in the base year of data collection. This present paper will discuss about the children at the highest risk for which it will focus on two categories of children first, the children who have been found repeating their grade, experienced long absenteeism (even for more than 15 days) and rated as very poor performers by their teachers in previous and also in base year of data collection. Second, in addition to these, there are others who have experienced simultaneously all these aspects i.e. low attendance, poor performance (as rated by teachers) as well as repetition of grades in both years. These children can also be categorized as 'most vulnerable children' or the children 'at the highest risk' of dropping out. In this paper an attempt has been made to identify such children and their socio-economic background. The analysis starts with a discussion on repeaters in both years followed by absenteeism and performance.

\section{Review of Related Literature:}

The review of existing related literature (Pratham, 2007; Reddy, 2004; Ramchandran et al., 2003; ASER, 2007; NUEPA, 2007; Colclough et al., 2001; Astone \& McLanahan, 1991; Rumberger et al., 1990; Alpert and Dunham, 1986; ) have explained about the nature and extent of risk students and also acknowledged who drop out and why from the perspectives of individual and school perspectives. Reviewing on the research studies both at individual and institutional levels regarding the causes of dropping out of the school, the existing related literature have consistently focused the following factors as indicators of risk for dropping out (fig -1):

- Low family income

- Lack of parental academic support

- Single-parent family

- Low educational status of the parents

- Punitive relationship in the family

- Low levels of learning

- Low achievement

- Being detained in the class

- Late age entry

- Grade-failure/ non-promotion

- School suspension

- Misbehaviour

- Inadequate social and academic school climate 


\section{[Figure- 1]}

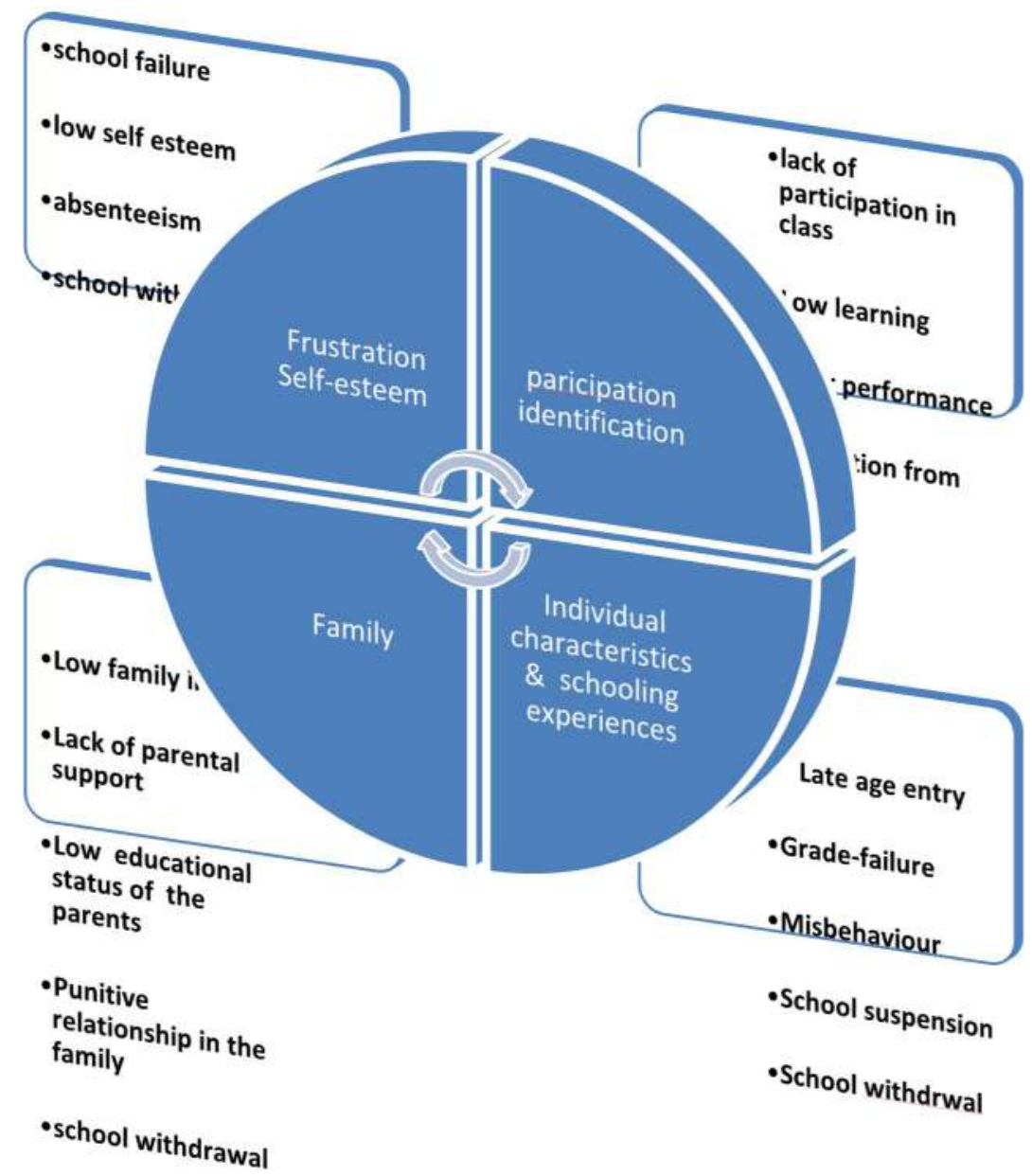

[Basing on the existing related literature this Conceptual Model was developed to explain the Process of Dropping Out]

\section{Methodology}

An empirical study was conducted in three clusters of Madhya Pradesh and Chhattisgarh. The study makes an attempt to make a comprehensive study of the most risk students of the primary and upper primary schools of rural areas of government schools of these taken areas. The sample consists of those students were selected based on their repetition, long absentees and poor performance in two consecutive years. A self developed survey questionnaire was used for the data collection purposes. The questionnaire contains the information of the sample students in respect to schooling levels, class-wise, school-wise, and village-wise and socioeconomic backgrounds. The analysis of the data was done quantitatively using simple descriptive statistics. 


\section{Major Findings:}

\section{Repetition:}

From the school roster data of base year and just one year after the base year, 10 out of 198 repeaters in Rajnandgaon, 53 out of 208 repeaters in Rewa and 29 out of 104 in Dindori registered as repeaters in school records. While more boys (6) than girls (4) were found among such repeaters in Rajnandgaon cluster, other two clusters in Rewa and Dindori had more number of female repeaters (24 were male and 29 were female in Rewa and 12 were male and 17 were female in Dindori). This indicates that both boys and girls are more or less in similar situation of vulnerability in these three clusters, though in Rewa and Dindori, girls are found to be in slightly more disadvantaged position.

\section{Repeaters in Primary and Upper Primary Levels:}

It is noticeable from the (table-1) that in Rajnandgaon, all ten repeaters who have repeated more than once are enrolled in primary level (the grade range from I-V), and such children were not found at the upper primary level. The situations in Rewa and Dindori do not differ much as these two clusters also have higher number of such repeaters at the primary grades. Thus in view of incidence of repetition, it is understandable that children even at the primary level are facing the highest risk of dropping out in all three clusters.

\section{Table: 1}

\begin{tabular}{|c|c|c|c|c|c|c|c|c|c|c|c|}
\hline Repe & OP & 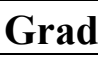 & Viso & Rajns & lo & Rewa & ad Di & dori & & & \\
\hline Rajn & ndga & & & Rewa & & & & Dind & & & \\
\hline $\begin{array}{l}\text { Gra } \\
\text { de }\end{array}$ & $\begin{array}{l}\text { Mal } \\
\text { e }\end{array}$ & $\begin{array}{l}\text { Fem } \\
\text { ale }\end{array}$ & Total & $\begin{array}{l}\text { Grad } \\
\text { e }\end{array}$ & $\begin{array}{l}\text { Mal } \\
\text { e }\end{array}$ & $\begin{array}{l}\text { Fem } \\
\text { ale }\end{array}$ & $\begin{array}{l}\text { Tota } \\
\text { l }\end{array}$ & $\begin{array}{l}\text { Gra } \\
\text { de }\end{array}$ & $\begin{array}{l}\text { Mal } \\
\text { e }\end{array}$ & $\begin{array}{l}\text { Fem } \\
\text { ale }\end{array}$ & $\begin{array}{l}\text { Tota } \\
\text { l }\end{array}$ \\
\hline $\mathrm{I}-\mathrm{V}$ & 6 & $\begin{array}{l}4 \\
(40 \\
\%)\end{array}$ & $\begin{array}{l}10 \\
(100 \\
\%)\end{array}$ & I-V & 16 & $\begin{array}{l}21 \\
(57 \\
\%)\end{array}$ & $\begin{array}{l}37 \\
(70 \\
\%)\end{array}$ & $\mathrm{I}-\mathrm{V}$ & 11 & $\begin{array}{l}17 \\
(61 \\
\%)\end{array}$ & $\begin{array}{l}28 \\
(97 \\
\%)\end{array}$ \\
\hline $\begin{array}{l}\text { VI- } \\
\text { VIII }\end{array}$ & & & & $\begin{array}{l}\text { VI- } \\
\text { VIII }\end{array}$ & 8 & $\begin{array}{l}8 \\
(50 \\
\%)\end{array}$ & $\begin{array}{l}16 \\
(30 \\
\%)\end{array}$ & $\begin{array}{l}\text { VI- } \\
\text { VIII }\end{array}$ & 1 & $\begin{array}{l}0 \\
(.0 \% \\
)\end{array}$ & $\begin{array}{l}1 \\
(3 \%)\end{array}$ \\
\hline $\begin{array}{l}\text { Gra } \\
\text { nd } \\
\text { Tota } \\
\text { l }\end{array}$ & $\begin{array}{l}6 \\
(60 \\
\%)\end{array}$ & $\begin{array}{l}4 \\
(40 \\
\%)\end{array}$ & 10 & $\begin{array}{l}\text { Gran } \\
\text { d } \\
\text { Total }\end{array}$ & $\begin{array}{l}24 \\
(45 \\
\%)\end{array}$ & $\begin{array}{l}29 \\
(55 \\
\%)\end{array}$ & 53 & $\begin{array}{l}\text { Gra } \\
\text { nd } \\
\text { Tota } \\
\text { l }\end{array}$ & $\begin{array}{l}12 \\
(41 \\
\%)\end{array}$ & $\begin{array}{l}17 \\
(59 \\
\%)\end{array}$ & 29 \\
\hline
\end{tabular}


Note: The figures in parenthesis represent percentage to total and italic figures in parenthesis represents percentage to grand total.

\section{Class-Wise Repeaters:}

The class-wise results show that most children with experience of repetition in both years are enrolled in early primary grades in Rajnandgaon. All of these children repeated the grades in both years in between the classes from $1^{\text {st }}$ to $3^{\text {rd }}$ grades and highest proportion of such repeaters are found in grade 3. In Rewa the highest proportion of children who have repeated the both years are found at $8^{\text {th }}$ grade followed by $6^{\text {th }}$ grade. In Dindori out of the total repeaters of both years, the highest numbers of children were found repeating the $1^{\text {st }}$ grade itself and majority of them were females. Thus in all the three clusters, potential drop outs who are at the highest risk are found to be struggling to learn even at the early years of schooling raising concern about the quality of primary schools in all these areas.

\section{School-Wise Repeaters:}

The school-wise data indicates that there are altogether 53 students who had repeated in both years in all the government primary and middle schools of Rewa. Among all the schools in Rewa, G.H.S.S. Dihiya has the highest number of children followed by G.P.M.S. Amiliki who have repeated both years. And the majority of these children were female in both the schools. In Dindori, out of the 29 repeaters of both years, the highest numbers of the children were found in P.S. Silpidi and majority of these children were female students. In Rajnandgaon there are two schools where majority of such repeaters were found. These are respectively Girls' G.P.S. Arjuni followed by Boys G.P.S. Arjuni.

\section{Repeaters in Village-Wise:}

The collected data reveals that out of 14 villages in Dindori, the village of Silpidi has the maximum numbers of children followed by Pandripani who had repeated both years of their schooling. Out of these children majority were female in Silpidi and majority were male in Pandripani. In the cluster of Rajnandgaon, the maximum number of children from Arjuni and Rampur had repeated the grades in both the years of their schooling. In Rewa the higher numbers of children who have repeated in both years are from Amiliki, Raura and Dihiya. Out of these repeaters female were accounted for higher proportion. 


\section{Economic background of repeaters:}

As per the economic conditions of the children who have repeated in both years, majority of children belong to Non-BPL households in Rajnandgaon. The similar is the situation in Rewa as it was in Rajnandgaon. But the condition of Dindori is altogether different from Rajnandgaon and Rewa. The majority of the children in Dindori who have repeated both the years were belonged to BPL households and higher proportion was female repeaters. It may be because most of the people are found to be in the BPL category which indicates they are in abysmally lower economic condition.

As regards to the monthly income of the household's majority of the children were belonged to the family income of less than 3000 and very few were belonged to the family income of more than 3000 as evident in all the three clusters of Rajnandgaon, Rewa and Dindori.

\section{Repeaters in Caste-Wise:}

Table: 2

\begin{tabular}{|c|c|c|c|c|c|c|c|c|c|}
\hline \multicolumn{10}{|c|}{ Repeaters in Caste-Wise in Rajnandgaon, Rewa and Dindori } \\
\hline \multicolumn{4}{|c|}{ Rajnandgaon } & \multicolumn{3}{|c|}{ Rewa } & \multicolumn{3}{|c|}{ Dindori } \\
\hline Caste & Male & $\begin{array}{l}\text { Femal } \\
\text { e }\end{array}$ & Total & Male & Female & Total & Male & Female & Total \\
\hline $\mathrm{SC}$ & & & & 7 & $9(56 \%)$ & $\begin{array}{l}16 \\
(30 \%)\end{array}$ & & & \\
\hline ST & 1 & $\begin{array}{l}0 \\
(.0 \%)\end{array}$ & $\begin{array}{l}1 \\
(10 \%)\end{array}$ & 3 & $1(25 \%)$ & $4(8 \%)$ & 11 & $\begin{array}{l}16 \\
(59 \%)\end{array}$ & $\begin{array}{l}27 \\
(93 \%)\end{array}$ \\
\hline $\mathrm{OBC}$ & 5 & $\begin{array}{l}4 \\
(44 \%) \\
\end{array}$ & $\begin{array}{l}9 \\
(90 \%) \\
\end{array}$ & 12 & $\begin{array}{l}16(57 \% \\
)\end{array}$ & $\begin{array}{l}28 \\
(53 \%) \\
\end{array}$ & 1 & $1(50 \%)$ & $2(7 \%)$ \\
\hline General & & & & 2 & $3(60 \%)$ & $5(9 \%)$ & & & \\
\hline $\begin{array}{l}\text { Grand } \\
\text { Total }\end{array}$ & $\begin{array}{l}6 \\
(60 \%)\end{array}$ & $\begin{array}{l}4 \\
(40 \%)\end{array}$ & 10 & $\begin{array}{l}24 \\
(45 \%)\end{array}$ & $\begin{array}{l}29 \\
(55 \%)\end{array}$ & 53 & $\begin{array}{l}12 \\
(41 \%)\end{array}$ & $\begin{array}{l}17 \\
(59 \%)\end{array}$ & 29 \\
\hline
\end{tabular}

Note: The figures in parenthesis represent percentage to total and italic figures in parenthesis represents percentage to grand total.

It is clearly observable that Rajnandgaon is mostly OBC dominated area, whereas Rewa is OBC and SC dominated and Dindori is ST dominated areas as per the Census 20011. The analysis of repeaters in caste-wise (table-2) indicates that majority of children who repeated in both years were belonged to Other Backwards Classes in Rajnandgaon. Out of these children males accounted for higher proportion. In Rewa the highest proportion of the repeaters were belonged to OBC followed by 
Scheduled Castes. However Scheduled Tribes were accounted for highest proportion in category of repeaters in Dindori and majority of them were the female children. Thus ST children are considered as the most risk children in Dindori district.

\section{Overall observations of Repetition in three clusters:}

From the above analysis it is found that there are altogether 92 children studying both in primary and upper primary levels of schooling repeated the grades in both the years and is found that majority of repeaters are from primary level in all the three areas. Thus the repeaters at the primary level are facing the highest risk of dropping out in all three clusters. The highest number of repeaters of both years occurred at $3^{\text {rd }}$ grade in Rajnandgaon; $8^{\text {th }}$ grade in Rewa; and $1^{\text {st }}$ grade in Dindori. Therefore, grade-III in Rajnandgaon, grade-I in Dindori and grade-VIII in Rewa are the highest risk grades. In Rajnandgaon Girls G.P.S. Arjuni and Boys G.P.S. Arjuni, whereas in Rewa G.H.S.S. Dihiya and GPMS. Amiliki and in Dindori P.S. Silpidi have higher numbers children who have repeated the grades in both years of their schooling life. The village-wise analysis indicates that the majority of repeaters of both years are found from the villages like- Arjuni and Rampur, in Rajnandgaon; Dihiya, Amiliki and Raura in Rewa; and Silpidi and Pandripani in Dindori. The highest numbers of repeaters are belonged to OBC in Rajnandgaon, both $\mathrm{OBC}$ and SC in Rewa and ST in Dindori. In view of the economic conditions of the households of the repeaters of both years it is found that majority of children are from poor households in the three clusters. Moreover, within Rewa and Dindori majority of children repeated in both the years are from very poor economic households.

\section{Absenteeism:}

It is found that there are few children who have remained absent for more than 15 days in both years in the month ( previous month of data collection) in schools registers, who are come under the category of most vulnerable children in three clusters. The total numbers of children who remained absent for more than 15 days in Rajnandagaon are 5 (4 were female and 1 was male); 10 were in Rewa ( 6 were male and 4 were female); and 3 were in Dindori. The three absentees in Dindori were all male children. Though male students are slightly more in numbers than female students in Rewa and Dindori, the situation is not much differed from Rajnandgaon despite female were slightly having more in number than male. This clearly indicates that both boys and girls are more or less in similar situation of vulnerability in these three clusters. The detailed analyses of these children are discussed in the following manner. 


\section{Absenteeism in Primary and Upper Primary Levels:}

It is clearly visible from the table (table-3) that in Rajnandgaon, out of all five, four absentees who remained absent in both years are enrolled in primary level (the grade range from I-V) and one at upper primary level. The situations in Rewa and Dindori do not differ much as these two clusters also have higher number of such absentees at the primary grades.

Table: 3

\begin{tabular}{|c|c|c|c|c|c|c|c|c|c|c|c|}
\hline \multicolumn{12}{|c|}{ Absenteeism in Grade-Wise in Rajnandgaon,Rewa and Dindori } \\
\hline \multicolumn{4}{|c|}{ Rajnandgaon } & \multicolumn{4}{|c|}{ Rewa } & \multicolumn{4}{|l|}{ Dindori } \\
\hline Grade & $\begin{array}{l}\text { Mal } \\
\text { e }\end{array}$ & $\begin{array}{l}\text { Femal } \\
\text { e }\end{array}$ & $\begin{array}{l}\text { Tot } \\
\text { al }\end{array}$ & Grade & $\begin{array}{l}\text { Mal } \\
\text { e }\end{array}$ & $\begin{array}{l}\text { Femal } \\
\text { e }\end{array}$ & $\begin{array}{l}\text { Tot } \\
\text { al }\end{array}$ & Grade & $\begin{array}{l}\text { Mal } \\
\text { e }\end{array}$ & $\begin{array}{l}\text { Femal } \\
\text { e }\end{array}$ & $\begin{array}{l}\text { Tot } \\
\text { al }\end{array}$ \\
\hline I-V & 1 & 3 & 4 & $\mathbf{I}-\mathbf{V}$ & 4 & 2 & 6 & I-V & 3 & $\mathbf{0}$ & 3 \\
\hline VI-VIII & $\mathbf{0}$ & 1 & 1 & $\begin{array}{l}\text { VI- } \\
\text { VIII }\end{array}$ & 2 & 2 & 4 & VI-VIII & & & \\
\hline $\begin{array}{l}\text { Grand } \\
\text { Total }\end{array}$ & 1 & 4 & 5 & & 6 & 4 & 10 & $\begin{array}{l}\text { Grand } \\
\text { Total }\end{array}$ & 3 & $\mathbf{0}$ & 3 \\
\hline
\end{tabular}

\section{Class-Wise Absenteeism:}

The class-wise results of absenteeism reveal that children are more vulnerable at the primary classes than the upper primary classes in Rajnandgaon, and Dindori. Majority of these children have remained absent for more than 15 days in both years in between the classes from $1^{\text {st }}$ to $4^{\text {th }}$ grades in Rajnandgaon. The similar was the situation in Dindori. However the situation in Rewa is slightly different from these two clusters. The major proportions of absentees were found in the primary classes as well as in upper primary classes.

\section{School-Wise Absenteeism:}

The school-wise data indicates in Rajnandgaon G.P.S. Rudgaon; G.P.M.S. Amiliki in Rewa; and P.S. Tarach in Dindori had higher number of absentees who remained absent more than 15 days in the month in both the years.

\section{Village-Wise Absenteeism:}

The analysis of raw data clearly reveals that out of total villages where the total number of absentees resides; Rudgaon is comparatively is worst condition than the villages like Arjuni, Kotrasarar 
and Ammlidih in Rajnandgaon cluster and Tarach in Dindori cluster. In Rewa cluster, the maximum numbers of children from Amilik had remained absent in both the years of their schooling career.

\section{Economic backgrounds of absentees:}

While analyzing the economic background data that demonstrates that the economic conditions of the children who have remained absent in both years, majority of children are belonged to BPL households in Rajnandgaon. The similar is the situation in Rewa as it was in Rajnandgaon. But the condition of Dindori is almost same as other two clusters. As regards to the monthly income of the household's almost all the children were belonged to the family income of less than 3000 as evident in all the three clusters.

\section{Absentees in Different Social Groups:}

The analysis of repeaters in caste-wise (table-4) indicates that all children who remained absent in both years were belonged to Other Backwards Classes in Rajnandgaon. Out of these children females were accounted for higher proportion. In Rewa the highest proportion of the absentees were belonged to Scheduled Castes followed by $\mathrm{OBC}$ and General caste. However Scheduled Tribes' children were accounted for highest proportion in category of absenteeism in Dindori.

Table: 4

\begin{tabular}{|l|l|l|l|l|l|l|l|l|l|l|}
\hline \multicolumn{9}{|l|}{ Absenteeism in Caste-Wise in Rajnandgaon, Rewa and Dindori } \\
\hline Rajnandgaon & Rewa & $\begin{array}{l}\text { Fema } \\
\text { le }\end{array}$ & Total & Male & $\begin{array}{l}\text { Fema } \\
\text { le }\end{array}$ & Total & Male & $\begin{array}{l}\text { Fem } \\
\text { ale }\end{array}$ & Total \\
\hline SC & Maste & & & 3 & 1 & $\mathbf{4}$ & & & \\
\hline ST & & & & & & & 2 & 0 & $\mathbf{2}$ \\
\hline OBC & 1 & 4 & $\mathbf{5}$ & 2 & 1 & $\mathbf{3}$ & 1 & 0 & $\mathbf{1}$ \\
\hline General & & & & 1 & 2 & $\mathbf{3}$ & & & \\
\hline $\begin{array}{l}\text { Grand } \\
\text { Total }\end{array}$ & $\mathbf{1}$ & $\mathbf{4}$ & $\mathbf{5}$ & $\mathbf{6}$ & $\mathbf{4}$ & $\mathbf{1 0}$ & $\mathbf{3}$ & $\mathbf{0}$ & $\mathbf{3}$ \\
\hline
\end{tabular}

\section{Overall observations of Long Absentees in three clusters:}

The overall situation of long absenteeism in the three selected areas reveal that three are altogether 18 children who had remained absent for more than 15 days in the month in the school registers in both the years. And the majority of students who remained long absent in both the years of 
their schooling are from primary level in the three clusters. Thus the grades in primary level are most critical stages for the children who frequently remained absent. The school-wise analysis indicates that in Rajnandgaon G.P.S. Rudgaon; G.P.M.S. Amiliki in Rewa; and P.S. Tarach in Dindori had higher number of absentees who remained absent more than 15 days in the month in both the years. Similarly, village-wise analysis shows that village like Rudgaon in Rajnandgaon; Amilik in Rewa; and Tarach in Dindori have the higher numbers of absentees of both years. The major proportion of absentees is found from OBC in Rajnandgaon, SC in Rewa and ST in Dindori. It is also found all absentees in the three clusters are belonging to poor economic households.

\section{Poor Performance:}

It was found that there are altogether 12 children who had performed very poor as per the teachers' ratings in both years of the above three clusters. As per the school roster data of 2008 and 2009, 6 out of 211 poor performers in Rajnandgaon, 5 out of 137 in Dindori and 1 out of 113 in Rewa found to be poor performers in both consecutive years. While one girl was found as poor performer in Rewa cluster, other two clusters in Rajnandgon and Dindori had more number of male poor performer ( 4 were male and 2 were female in Rajnandgaon and 5 all were male in Dindori). This indicates that boys are disadvantaged position in Rajnandgaon and Dindori cluster. The detailed analyses of these children are discussed in the following manner.

\section{Poor Performance in Primary and Upper Primary Levels:}

It is clearly visible from the table (table-5) that in Rajnandgaon, all six children, and in Dindori all five children who had performed poor as per teachers are enrolled in primary level (the grade range from I-V). The situation in Rewa is differed from these two clusters as one poor performer in this cluster is from upper primary level.

Table: 5

\begin{tabular}{|c|c|c|c|c|c|c|c|c|c|c|c|}
\hline \multicolumn{12}{|c|}{ Performance in Grade-Wise in Rajnandgaon,Rewa and Dindori } \\
\hline \multicolumn{4}{|c|}{ Rajnandgaon } & \multicolumn{4}{|c|}{ Rewa } & \multicolumn{4}{|l|}{ Dindori } \\
\hline Grade & $\begin{array}{l}\text { Mal } \\
\text { e }\end{array}$ & $\begin{array}{l}\text { Femal } \\
\text { e }\end{array}$ & $\begin{array}{l}\text { Tot } \\
\text { al }\end{array}$ & $\begin{array}{l}\text { Grad } \\
\text { e }\end{array}$ & $\begin{array}{l}\text { Mal } \\
\text { e }\end{array}$ & $\begin{array}{l}\text { Femal } \\
\text { e }\end{array}$ & $\begin{array}{l}\text { Tot } \\
\text { al }\end{array}$ & Grade & $\begin{array}{l}\text { Mal } \\
\text { e }\end{array}$ & $\begin{array}{l}\text { Femal } \\
\text { e }\end{array}$ & $\begin{array}{l}\text { Tot } \\
\text { al }\end{array}$ \\
\hline $\mathrm{I}-\mathrm{V}$ & 4 & 2 & 6 & $\mathrm{I}-\mathrm{V}$ & & & & $\mathrm{I}-\mathrm{V}$ & 5 & 0 & 5 \\
\hline VI-VIII & & & & $\begin{array}{l}\text { VI- } \\
\text { VIII }\end{array}$ & 0 & 1 & $\mathbf{1}$ & VI-VIII & & & \\
\hline Grand & 4 & 2 & 6 & & $\mathbf{0}$ & 1 & 1 & Grand & 5 & $\mathbf{0}$ & 5 \\
\hline
\end{tabular}




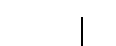

\section{Class-Wise Poor Performance:}

The class-wise results of performance reveal that children are more vulnerable at the primary classes than the upper primary classes in Rajnandgaon and Dindori clusters. All these children have performed very poor in both years in between the classes from $1^{\text {st }}$ to $5^{\text {th }}$ grades.

\subsubsection{School-Wise Poor Performance:}

The school-wise data indicates in Rajnandgaon G.P.S. Rudgaon and P.S.Silpidi in Dindori had comparatively higher number of poor performers as compared to other schools in these two clusters.

\section{Village-Wise Poor Performance:}

The collected data clearly reveals that out of total villages where the total number of poor performers resides; Rudgaon and Aari are comparatively in worst conditions than the villages like Arjuni, Sonesarar in Rajnandgaon cluster and Silpidi in Dindori cluster.

\section{Economic backgrounds of poor performers:}

The situations of poor performers indicates that the economic conditions of the children households who performed very poor in both years, majority of children were belonged to BPL households in Rajnandgaon. The similar is the situation in Dindori as it was in Rajnandgaon. As regards to the monthly income of the household's majority of poor performers in Rajnandgaon were belonged to the family income of less than 3000 and majority of poor performers in Dindori were belonged to very poor economic households.

\section{Poor Performers among Different Social Groups:}

The analysis of children who performed very poor in caste-wise (table-6) indicates that majority of children who performed very poor in both years were belonged to Other Backwards Classes in Rajnandgaon. Out of these children males were accounted for higher proportion. In Dindori the highest proportion of the poor performers was belonged to Scheduled Tribes and all of them were males. 
Table: 6

\begin{tabular}{|l|l|l|l|l|l|l|l|l|l|l|l|}
\hline \multicolumn{9}{|l|}{ Poor Performances in Caste-Wise in Rajnandgaon, Rewa and Dindori } \\
\hline Rajnandgaon & Male & Female & Total & Male & Female & Total & Male & Female & Total \\
\hline Caste & & & & & & & & & \\
\hline SC & 0 & 1 & $\mathbf{1}$ & 4 & 0 & $\mathbf{4}$ & & & \\
\hline ST & 4 & 1 & $\mathbf{5}$ & 1 & 0 & $\mathbf{1}$ & 0 & 1 & $\mathbf{1}$ \\
\hline OBC & & & & & & & & & \\
\hline General & & $\mathbf{2}$ & $\mathbf{6}$ & $\mathbf{5}$ & $\mathbf{0}$ & $\mathbf{5}$ & $\mathbf{0}$ & $\mathbf{1}$ & $\mathbf{1}$ \\
\hline Grand Total & $\mathbf{4}$ & &
\end{tabular}

\section{Conclusion and Suggestions:}

The results of the study indicates that majority of most vulnerable children are found at primary level in all the three clusters. Majority of repeaters, majority of long absentees and poor performers are facing the highest risk of dropping out at the primary levels. Similarly, the most vulnerable children are basically belonging to the lower social ladder of the society. The children who belong to Other Backward Classes (OBC) are basically found in Rajnandgaon cluster of Chhattisgarh State while in Rewa and Dindori Clusters of Madhya Pradesh these children were belonged to Scheduled Castes (SCs) and Scheduled Tribes (STs). Further, it was also found from the study that these most vulnerable children were from very poor socioeconomic backgrounds. Because of the financially poor family conditions they were not properly guided by their parents nor received any emotional or academic supports from other sections of the society due to their social backward status in the society. Thus, in order to give them social justice to complete a basic level of primary education in rural areas, government must take pro active policy actions to include these most vulnerable children in the mainstreaming of education. There is a utmost need to improve the dilapidated conditions of primary government schools in the rural areas so that each and every children can get adequate quality of education easily accessible to them. The school must also to take active steps to educate the parents and timely inform the parents about the academic progress of their children in schools. Parents must be motivated to get involved as a support system for their children. 
Towards Excellence: An Indexed, Refereed \& Peer Reviewed Journal of Higher Education / Dr. Pankaj Das / Page $\underline{298-310}$

\section{Reference}

Alpert, G., and R. Dunham. "Keeping Academically Marginal Youths in School”. Youth and Society, 17, 1986. 346-361.

Astone, N. M., \& McLanahan, S.S. "Family structure, parental practices and high school completion". American Sociological Review, 56, 1991. 309-320.

Boyle, S., Brock, Mace, J., and Sibbons, M. Reaching the Poor: The 'Costs' of sending Children to School. Synthesis report. London: DFID. 2002.

Colclough, C. \& Lewin, K.. Educating all the Children: strategies for primary education in the south (Oxford, Clarendon Press). 1993.

Das, P. "Girls at Risk: Investigating the Extent and Process of Dropping Out in Elementary Education in India", International Journal of Learner Diversities and Identities, Vol. 19 (1), 2013. 1-18.

Hunt, F. Dropping out of School: A Cross country Review of Literature, CREATE Pathways to Access, Research Monograph No. 16. Falmer: CREATE. 2008.

Pratham . Annual Status of Education Report 2006. New Delhi. 2007.

PROBE. Public Report on Basic Education in India. New Delhi: Oxford University Press. 1999.

Ramachandran, V., Jandhyala, K. and Saihjee, A. Through the Life Cycle of Children: Factors that Facilitate/ Impede Successful Primary School Completion. EPW, 22 November, 2003. 4994-5002.

Reddy, S. The Social Context of Elementary Education in Rural India. Bangalore: Azim Premji Foundation. 2004.

Rumberger, R. W., Ghatak, R., Poulos, G., Ritter, Philip L., and Dornbush, S. M. "Family Influences on Dropout Behaviour in One California High School”, Sociology of Education, Vol. 63(4), 1990. 283-299.

\section{Dr. Pankaj Das \\ Assistant Professor \\ School of Education, Sharda University \\ Greater Noida, Uttar Pradesh, India \\ E-mail: daspankaj4@gmail.com}

